\title{
The Impact of Total Quality Management on the Effectiveness of Educational Programs of Karaj First Grade High Schools
}

\author{
Nayereh Shahmohammadi \\ Organization for Educational Research and Planning (OERP) \\ Ministry of Education \\ Tehran, Iran \\ Nsh_teh@yahoo.com
}

\begin{abstract}
This study aimed to explore the role of total quality management (TQM) in educational programs of first grade high schools in Karaj city. The target population included all high school teachers of the academic year 2015-2016. Sample population of 324 persons was selected by random cluster sampling. A questionnaire was used to measure the variables in the study. Content validity of the questionnaire was confirmed by experts. The reliability of the questionnaire was estimated to be 0.89 by Cronbach's alpha coefficient. T-test was used to analyze the data. The results showed that TQM and each of its dimensions affect the effectiveness of training programs and courses in junior high schools in the city of Karaj.
\end{abstract}

Keyword-total quality management; effectiveness; training; quality; education; analysis

\section{INTRODUCTION}

Enterprise development depends on the promotion of knowledge, skills, and insights of employees. As a tool for development, education meets the needs of organizations. Sustainable development in different dimensions depends on education, its quality, continuity and effectiveness $[1,2]$. The improvement of human resources through education in general and high quality and effective in-service training in particular is the most effective means to create harmony between employees and organizations [3]. Authors in [4] argue that educational effectiveness depends largely on teachers' effectiveness. The educational effectiveness of teachers should be evaluated based on the behavior and learning of students. The theoretical and research literature indicate that the major obstacles of educational programs which have reduced the efficiency and effectiveness of education over the years are associated with educational programs themselves. In [5], factors such as lack of skilled labor, lack of participation of education stakeholders in program designing, lack of evaluation in educational system, and not using evaluation results to reform educational process affected the effectiveness of training programs are reported. Education management experts consider total quality management (TQM) as an important tool for the reconstruction of the educational system and for increasing its effectiveness [6]. TQM consists of many components including leadership, data analysis, benchmarking, quality strategic planning, human resources development, products and services quality assurance, and customer satisfaction [7]. There are many studies on the application of TQM on educational systems. In [8] it was found that there was significant relationship between TQM application in schools and leading teachers by principals, helping students, constructive relations with parents, skill evaluation and school administration. Authors in [9] defined that the application of TQM in education has a strategic and systematic approach that includes seven steps. Authors in [10] claimed that four major principles of TQM have not been considered properly. Authors in a similar study [6] found that there is a significant and positive correlation between the deployment of TQM and effectiveness. In [11], the attitudes of professors, students, and teachers (from preschool to high school) toward the role, appropriateness, and application of TQM in education were evaluated. The findings showed that teachers have less resistance to implement it than other groups. Author in [12] studied the implementation of TQM in New Jersey schools. He identified five factors which help to implement TQM in organizations: 1) efforts should be based on the improvement process, 2) quality should be identified and defined by customers, 3) everyone must be involved in decision-making, 4) decision must be made based on data and results, and 5) a long-term commitment should be created by top management. The necessity of TQM, as an important factor for effectiveness of training programs, is more important than ever. This study aims to investigate the impact of TQM on the effectiveness of training programs of first grade high school in Karaj in order to help practitioners and stakeholders to consider TQM and control continuously its indicators to identify the key factors for strengthening the effectiveness of training programs and provide grounds for improving them.

\section{METHODOLOGY}

This study applied a descriptive survey. It assessed the perspective of teachers about the quality and effectiveness of training programs considering quality management. The population consisted of all first grade high school teachers in Karaj in 2015-2016 ( $\mathrm{N}=2073)$. Using Cochran's formula and 
random cluster sampling method, 324 teachers were selected as participants. Moghimi's TQM evaluation questionnaire [13] was used as research tool. It included 39 questions which evaluated the impact of each of the eight TQM dimensions, shown in Table I, on the effectiveness of educational programs from the teachers' perspective. Questionnaire's content validity was confirmed by 12 experts. To determine the reliability of the questionnaire, it was distributed among 30 subjects. Using Cronbach's alpha, the reliability was determined to be 0.89 (Table II). The descriptive (frequency, percentage, mean, and standard deviation) and inferential (Kolmogorov - Smirnoff to assess the normality of population, one sample t-test) statistics were used for data analyzing.

TABLE I. QUESTIONNAIRE DIMENSIONS

\begin{tabular}{|c|c|}
\hline Dimension & Questions \\
\hline Support and leadership & 1 to 4 \\
\hline Strategic planning & 5 to 11 \\
\hline Customer orientation & 12 to 17 \\
\hline Staff identification and training of & 18 to 23 \\
\hline Empowerment of employees and teamwork & 24 to 29 \\
\hline Quality measurement and analysis & 30 to 33 \\
\hline Quality assurance & 34 to 36 \\
\hline $\begin{array}{c}\text { Outcomes of efficiency and quality } \\
\text { improvement }\end{array}$ & 37 to 39 \\
\hline
\end{tabular}

TABLE II. RELIABILITY OF QUESTIONNAIRE

\begin{tabular}{|c|c|c|}
\hline Row & Dimension & $\begin{array}{c}\text { Reliability } \\
\text { coefficient }\end{array}$ \\
\hline 1 & Support and leadership & 0.84 \\
\hline 2 & Strategic planning & 0.75 \\
\hline 3 & Customer orientation & 0.81 \\
\hline 4 & Identification and training of staff & 0.91 \\
\hline 5 & Empowerment of employees and teamwork & 0.82 \\
\hline 6 & Quality measurement and analysis & 0.84 \\
\hline 7 & Quality assurance & 0.80 \\
\hline 8 & Outcomes of efficiency and quality & 0.75 \\
\hline 9 & improvement & 0.89 \\
\hline
\end{tabular}

\section{FINDINGS}

Using descriptive statistics, the demographic characteristics (gender, age, education, and work experience) of participants were investigated. These characteristic are shown in Table III. Before testing the study hypotheses, the normality of data frequency distribution was investigated using KolmogorovSmirnoff's goodness of fit test. Results are presented in Table IV. As shown, all data have a normal distribution and the parametric statistics may be used for analysis. Therefore, the one-sample t-test was used to test the main hypothesis (TQM) and consequent sub-hypotheses. Main hypothesis: TQM has impact on the effectiveness of first grade high school educational programs in Karaj. According to Table V, the mean score of impact of TQM on the effectiveness of first grade high school educational programs in Karaj is 3.23. The calculated $t$ is larger than the critical $\mathrm{t}=8.47$. Therefore, the impact of TQM on the effectiveness of first grade high school educational programs in Karaj is statistically significant. This is consistent with findings in [8], where author found that there was a significant relationship between applying TQM in schools and principal leadership, appropriate behavior of teachers, helping of students, constructive relations with parents, evaluation skills, and management of affairs. Schools that use TQM pay special attention to students, teachers, and meet their needs and demands. In these schools, all employees including teachers and students are in good terms and staff members are involved in enriching and improving school's quality. Improvement of all school elements and factors is performed based on principles of TQM [7].

TABLE III. PARTICIPANTS DEMOGRAPHIC CHARACTERISTICS

\begin{tabular}{|c|c|c|c|}
\hline \multicolumn{2}{|c|}{ Demographic Variable } & Frequency & Percentage \\
\hline \multirow{4}{*}{ Gender } & Men & 189 & 58.3 \\
\cline { 2 - 4 } & Women & 135 & 41.7 \\
\hline \multirow{4}{*}{$\begin{array}{c}\text { Educational } \\
\text { Degree }\end{array}$} & $\begin{array}{c}\text { Associate } \\
\text { degree }\end{array}$ & 51 & 15.7 \\
\cline { 2 - 4 } & $\begin{array}{c}\text { Bachelor } \\
\text { degree }\end{array}$ & 182 & 56.2 \\
\cline { 2 - 4 } & $\begin{array}{c}\text { Master degree } \\
\text { and above }\end{array}$ & 91 & 28.1 \\
\hline \multirow{4}{*}{$\begin{array}{c}\text { Work } \\
\text { experience } \\
\text { (years) }\end{array}$} & $\mathbf{1 ~ t o ~ 5}$ & 32 & 9.9 \\
\cline { 2 - 4 } & $\mathbf{6}$ to 10 & 83 & 25.6 \\
\cline { 2 - 4 } & $\mathbf{1 1}$ to 15 & 88 & 27.2 \\
\cline { 2 - 4 } & $\mathbf{1 6}$ to 20 & 81 & 25 \\
\hline \multirow{4}{*}{ Age } & $\mathbf{2 1}$ and above & 40 & 12.3 \\
\cline { 2 - 4 } & $\mathbf{2 0}$ to 30 & 55 & 17 \\
\cline { 2 - 4 } & $\mathbf{3 1}$ to 0 & 146 & 45.1 \\
\cline { 2 - 4 } & $\mathbf{4 1}$ to 50 & 105 & 32.4 \\
\hline 51 and above & 18 & 5.6 \\
\hline
\end{tabular}

TABLE IV. KOLMOGOROV-SMIRNOFF'S TEST

\begin{tabular}{|c|c|c|c|c|}
\hline Dimension & Frequency & $\begin{array}{c}\text { Kolmogorov- } \\
\text { Smirnoff's } \\
\text { test }\end{array}$ & $\begin{array}{c}\text { Significance } \\
\text { level }\end{array}$ \\
\hline 1 & $\begin{array}{c}\text { Support and } \\
\text { leadership }\end{array}$ & 324 & 1.17 & 0.106 \\
\hline 2 & Strategic planning & 324 & 0.824 & 0.429 \\
\hline 3 & $\begin{array}{c}\text { Customer } \\
\text { orientation }\end{array}$ & 324 & 0.920 & 0.298 \\
\hline 5 & $\begin{array}{c}\text { Staff identification } \\
\text { and training }\end{array}$ & 324 & 0.576 & 0.638 \\
\hline 6 & $\begin{array}{c}\text { Empowerment of } \\
\text { employees and } \\
\text { teamwork }\end{array}$ & 324 & 0.813 & 0.492 \\
\hline $\begin{array}{c}\text { Quality } \\
\text { mearement and }\end{array}$ & 324 & 1.22 & 0.154 \\
\hline 7 & Quality assurance & 324 & 1.02 & 0.572 \\
\hline 8 & $\begin{array}{c}\text { Outcomes of } \\
\text { efficiency and } \\
\text { quality } \\
\text { improvement }\end{array}$ & 324 & 0.793 & \\
\hline
\end{tabular}

First sub-hypothesis: Support and leadership of senior management dimension of TQM has impact on the effectiveness of first grade high school educational programs in Karaj. According to Table VI, the mean score of impact of support and leadership of senior management dimension of TQM is 3.16. The calculated $t$ (3.52) is larger than the critical t. Therefore, the impact of support and leadership of senior management dimension of TQM is statistically significant. 
This is consistent with findings in [6] where author found that there is significant relationship between managers' knowledge of TQM and teachers' effectiveness. Findings also showed that the more managers support these programs, the more schools will naturally try to provide better programs to students [14]. The support is an effective component to achieve and improve the quality of education [15].

Second sub-hypothesis: Strategic planning dimension of TQM has impact on the effectiveness of first grade high school educational programs in Karaj. According to Table VII, the mean score of impact of strategic planning dimension of TQM is 3.16. The calculated $t$ is larger than the critical. Therefore, the impact of strategic planning dimension of TQM is statistically significant. This is consistent with findings in [6, 8]. When the schools consider the necessity of strategic planning, the individuals or organizations involved in planning should be identified, the planning steps should be described and the needed resources should be specified. Staff will perform better and have more motivation to work and the educational programs will be more effective. Schools should adjust their direction based on strategic planning and changing environment, because strategic planning improves performance and meets the needs of a changing environment [16].

TABLE V. ONE SAMPLE T-TEST OF TQM'S ROLE ON THE EFFECTIVENESS OF EDUCATIONAL PROGRAMS

\begin{tabular}{|c|c|c|c|c|c|c|}
\hline Component & Average & $\begin{array}{c}\text { Assumed } \\
\text { mean }\end{array}$ & SD & t & Df & P \\
\hline $\begin{array}{c}\text { Total quality } \\
\text { management } \\
\text { on } \\
\text { educational } \\
\text { program } \\
\text { effectiveness }\end{array}$ & 3.23 & 3 & 0.491 & 8.47 & 323 & 0 \\
\hline
\end{tabular}

TABLE VI. ONE SAMPLE T-TEST ON TQM'S SUPPORT AND LEADERSHIP OF SENIOR MANAGEMENT DIMENSION ON THE EFFECTIVENESS OF EDUCATIONAL PROGRAMS

\begin{tabular}{|c|c|c|c|c|c|c|}
\hline Component & Average & $\begin{array}{c}\text { Assumed } \\
\text { mean }\end{array}$ & SD & t & Df & P \\
\hline $\begin{array}{c}\text { Support and } \\
\text { leadership } \\
\text { on } \\
\text { educational } \\
\text { programs } \\
\text { effectiveness }\end{array}$ & 3.16 & 3 & 0.862 & 3.52 & 323 & 0 \\
\hline
\end{tabular}

TABLE VII. ONE SAMPLE T-TEST ON TQM'S STRATEGIC PLANNING DIMENSION ON THE EFFECTIVENESS OF EDUCATIONAL PROGRAMS

\begin{tabular}{|c|c|c|c|c|c|c|}
\hline Component & Average & $\begin{array}{c}\text { Assumed } \\
\text { mean }\end{array}$ & SD & t & Df & P \\
\hline $\begin{array}{c}\text { Strategic } \\
\text { planning } \\
\text { dimension } \\
\text { on } \\
\text { educational } \\
\text { program } \\
\text { effectiveness }\end{array}$ & 3.16 & 3 & 0.863 & 3.52 & 323 & 0 \\
\hline
\end{tabular}

Third sub-hypothesis: Customer-orientation dimension of TQM has impacts on the effectiveness of first grade high school educational programs in Karaj. According to Table VIII, the mean score of the impact of customer-orientation dimension of TQM on effectiveness is 3.29. The calculated $t$ (5.38) is larger than the critical t. Therefore, the impact of customer-orientation dimension of TQM on effectiveness is statistically significant. One of the ways for educational institutions, especially schools to differentiate their services from other organizations is providing continuously high quality programs, considering total quality [17]. Total quality management in classroom aims to involve students in continually improving skills and learning processes, encourage them to take responsibility of their own learning, and promote their ability at all learning levels based on concrete objectives. Meanwhile, TQM tries to turn the students, parents, and staff to active, automated, effective, and critical thinkers, in order for the school services to meet the community needs [18].

TABLE VIII. ONE SAMPLE T-TEST ON TQM'S CUSTOMER ORIENTATION DIMENSION ON THE EFFECTIVENESS OF EDUCATIONAL PROGRAMS

\begin{tabular}{|c|c|c|c|c|c|c|}
\hline Component & Average & $\begin{array}{c}\text { Assumed } \\
\text { mean }\end{array}$ & SD & t & Df & P \\
\hline $\begin{array}{c}\text { Customer } \\
\text { orientation } \\
\text { dimension } \\
\text { on } \\
\text { educational } \\
\text { program } \\
\text { effectiveness }\end{array}$ & 3.29 & 3 & 0.989 & 5.38 & 323 & 0 \\
\hline
\end{tabular}

Fourth sub-hypothesis: Training of staff dimension of TQM has impact on the effectiveness of first grade high school educational programs in Karaj. According to Table IX, the mean score of the impact of training of staff dimension of TQM on effectiveness is 3.12. The calculated $t$ (2.24) is larger than the critical $t$, therefore, the impact of training of staff dimension of TQM is statistically significant. This is consistent with findings in $[6,8]$. It indicates that the planning for improving the quality of education makes learning enjoyable. The inclusion of quality in education means continuous changing and commitment [13]. In other words, high quality educational programs have an important influence on increasing organizational commitment and avoiding waste of knowledge and skills. Staff considers training as an important factor in their professional development [19].

Fifth sub-hypothesis: The employees' empowerment and teamwork dimension of TQM has impact on the effectiveness of first grade high school educational programs in Karaj. According to Table $X$, the mean score of impact of this dimension of TQM is 3.38. The calculated t (6.44) is larger than the critical t. Therefore, the impact of employees' empowerment and teamwork dimension of TQM is statistically significant. In other words, high capability managers and teachers perform well and successfully and improve the organization's activities. In fact, the empowerment is one of the factors affecting quality and effectiveness of educational programs. Managers and employees may provide better education if they have the ability to do their jobs, show competence and ability to work, and have sufficient 
proficiency. As a result, training programs will have better quality [8].

TABLE IX. ONE SAMPLE T-TEST ON TQM'S IDENTIFICATION AND TRAINING OF STAFF DIMENSION ON THE EFFECTIVENESS OF EDUCATIONAL PROGRAMS

\begin{tabular}{|c|c|c|c|c|c|c|}
\hline Component & Average & $\begin{array}{c}\text { Assumed } \\
\text { mean }\end{array}$ & SD & t & Df & P \\
\hline $\begin{array}{c}\text { Identification } \\
\text { and training of } \\
\text { staff } \\
\text { dimension on } \\
\text { educational } \\
\text { program } \\
\text { effectiveness }\end{array}$ & 3.12 & 3 & 1.02 & 2.24 & 323 & 0.025 \\
\hline
\end{tabular}

TABLE $X$. ONE SAMPLE T-TEST ON THE MPLOYEES' EMPOWERMENT AND TEAMWORK DIMENSION OF TQM ON THE EFFECTIVENESS OF EDUCATIONAL PROGRAMS

\begin{tabular}{|c|c|c|c|c|c|c|}
\hline Component & Average & $\begin{array}{c}\text { Assumed } \\
\text { mean }\end{array}$ & SD & T & Df & P \\
\hline $\begin{array}{c}\text { Employees' } \\
\text { empowerment } \\
\text { and teamwork } \\
\text { dimension on } \\
\text { the } \\
\text { educational } \\
\text { program } \\
\text { effectiveness }\end{array}$ & 3.38 & 3 & 1.07 & 6.44 & 323 & 0.000 \\
\hline
\end{tabular}

Sixth sub-hypothesis: Quality measurement and analysis dimension of TQM has impact on the effectiveness of first grade high school educational programs in Karaj. According to Table XI, the mean score of impact of quality measurement and analysis dimension of TQM is 3.13. The calculated $t$ (2.84) is larger than the critical. Therefore, the impact of quality measurement and analysis dimension of TQM is statistically significant. Quality measurement and analysis in schools is one of the factors which improve the quality of educational programs. As a control tool, it improves the performance of human resources. The impact of evaluation systems on organizational improvement and excellence gets more evident when the organization tries to conduct planned changes. Quality measurement and analysis aim to promote human resources in all aspects and cause employees to know their weaknesses, perform the organizational works well and successfully, and improve the organization's activities. This, makes individuals to have sufficient proficiency [6].

Seventh sub-hypothesis: The quality insurance dimension of TQM has impact on the effectiveness of first grade high school educational programs in Karaj. According to Table XII, the mean score of the impact of the quality insurance dimension of TQM is 3.29. The calculated $t$ (4.39) is larger than the critical $t$. Therefore, the impact of this dimension is statistically significant. When teachers have good teaching skills, teach with enthusiasm and interest, use practical tests for measuring and evaluating students, behave fairly to students, involve all students in educational activities and help students in solving their problems and weaknesses, the school will have high quality training programs [17].
TABLE XI. ONE SAMPLE T-TEST ON THE QUALITY MEASUREMENT AND ANALYSIS DIMENSION OF TQM ON THE EFFECTIVENESS OF EDUCATIONAL PROGRAMS

\begin{tabular}{|c|c|c|c|c|c|c|}
\hline Component & Average & $\begin{array}{c}\text { Assumed } \\
\text { mean }\end{array}$ & SD & t & Df & P \\
\hline $\begin{array}{c}\text { Quality } \\
\text { measurement } \\
\text { and analysis } \\
\text { dimension on } \\
\text { the } \\
\text { educational } \\
\text { program } \\
\text { effectiveness }\end{array}$ & 3.13 & 3 & 0.875 & 2.84 & 323 & 0.005 \\
\hline
\end{tabular}

TABLE XII. ONE SAMPLE T-TEST ON THE QUALITY INSURANCE DIMENSION OF TQM ON THE EFFECTIVENESS OF EDUCATIONAL PROGRAMS

\begin{tabular}{|c|c|c|c|c|c|c|}
\hline Component & Average & $\begin{array}{c}\text { Assumed } \\
\text { mean }\end{array}$ & SD & t & Df & P \\
\hline $\begin{array}{c}\text { Quality } \\
\text { Insurance } \\
\text { dimension } \\
\text { on } \\
\text { educational } \\
\text { programs } \\
\text { effectiveness }\end{array}$ & 3.29 & 3 & 1.19 & 4.39 & 323 & 0 \\
\hline
\end{tabular}

Eighth sub-hypothesis: The productivity and quality improvement dimension of TQM has impacts on the effectiveness of first grade high school educational programs in Karaj. According to Table XIII, the mean score of this dimension is 3.30. The calculated $t$ (5.3) is larger than the critical t. Therefore, the impact of this dimension is statistically significant. High quality education in schools means that the teachers perform school work and teaching well and successfully, use the experiences of others to improve their teaching practices, pay more attention to student problems, involve students in solving problems in classroom and pay attention to all students in classroom. Under this condition, students may learn better [20].

TABLE XIII. ONE SAMPLE T-TEST ON THE PRODUCTIVITY AND QUALITY IMPROVEMENT DIMENSION OF TQM ON THE EFFECTIVENESS OF EDUCATIONAL PROGRAMS

\begin{tabular}{|c|c|c|c|c|c|c|}
\hline Component & Average & $\begin{array}{c}\text { Assumed } \\
\text { mean }\end{array}$ & SD & T & Df & P \\
\hline $\begin{array}{c}\text { Productivity } \\
\text { and quality } \\
\text { improvement } \\
\text { dimension on } \\
\text { educational } \\
\text { program } \\
\text { effectiveness }\end{array}$ & 3.30 & 3 & 1.03 & 5.3 & 323 & 0 \\
\hline
\end{tabular}

\section{CONCLUSION}

This study explored the role of TQM in the educational programs of first grade high schools in Karaj city. The target population included all high school teachers of the academic year 2015-2016. A suitable and reliable questionnaire was used to measure the variables in the study. Result analysis showed that TQM and each of its dimensions affect the effectiveness of training programs and courses in junior high schools in the city 
of Karaj. The impact of each TQM dimension was documented and discussed.

\section{ACKNOWLEDGMENT}

Author would like to express her gratitude to all teachers in Karaj city who cooperated with her while conducting this study.

\section{REFERENCES}

[1] A. Youzbashi, Factors affecting the effectiveness of training courses in Naftiran Intertrade Company, MSc Thesis, Department of Psychology and Education, Tehran University, 2010

[2] S. Sahney, D. K. Banwet, S. Karunes, "An integrated framework for quality in education: Application of quality function deployment, interpretive structural modelling and path analysis", Total Quality Management \& Business Excellence, Vol. 17, No. 2, pp. 265-285, 2006

[3] F. Saadati Tabar, Satisfaction of beneficiaries from in-service training in Development and Renovation Organization in Iran, MSc Thesis, School of Management, Tehran University,2012

[4] G. J. Anderson, Fundamentals of educational research, Psychology Press, 1998

[5] M. B. Akbari Sari, Assessing vocational training needs of agricultural educators in training centers in Mazandaran, MSc Thesis, Faculty of Psychology and Educational Sciences, 2010

[6] F. Mahmoudi Khatoonabad, Awareness and adoption of Managers from total quality management (TQM) and its relation to effectiveness from vocational teachers' views in Karaj, MSc Thesis, Faculty of Management and Economics, PNU, 2011

[7] M. Abzari, A. Yazdkhasti, "Total Quality Management in Education", Sixth International Conference of Quality Managers, Tehran, Iran, June, 2005

[8] R. Jahanian, "The Relationship between Total Quality Management and Effectiveness of Managers in Tehran Secondary Schools", Journal of Management and Leadership, Vol. 3, No. 13, 2010
[9] M. Moghadam Yousef, M. Ali, J. Reza, "The Role of Exclusive Quality Management in the Advancement of Training Quality in I.R.I. Police University", Danesh-E-Entezami, Vol. 10, No. 3-4, pp. 181204, 2009

[10] R. Hoveyda, A. Siyadat, M. Es'haghian, "Comparing viewpoints of faculty members and students about application of measures of total quality management (TQM) in education process in Isfahan University", Journal of TQM, pp. 29-46, 2008

[11] D. Tomas, H. David, "Educator attitudes towards the appropriateness of Total Quality of Management in education", Dissertation Abstracts International, Vol. 56, No. 8, pp. 43-58, 1995

[12] J. Macdonald, Total quality management in a week, Hodder \& Stoughton, 1998

[13] M. Moghimi, Management \& Organization, Research approach, Terme Publishing, 2002

[14] K. Abeli, "Experiences of organizations effectiveness and assessing it in enterprises in Iran (weaknsses and solutions)", 1st International Conference of Education Administrators, 2009

[15] H. Abtahi, S. Abesi, Empowering employees Research and Training, Institute of Management, 2007

[16] A. Namavaran, A. Manafi, "Increasing the effectiveness of programs and educational opportunities and learning at different levels", Ronas Press, Vol. 3, No. 7, pp. 24-31, 2013

[17] A. Soghati, The relationship between total quality management and creativity and productivity of employees in Department of Education in Roodan, MSc Thesis, Marvdasht branch, Islamic Azad University, 2012

[18] F. Dordoi Nejad, The application of total quality management in teaching-learning process, Shahid Rajaee University, 2014

[19] A. A. Forughi Abri, M. A. Nadi, A. Ebrahimpour, "Factors affecting the quality of staff's in-service training in Islamic Azad University, Khorasghan Branch", Journal of Research and Curriculum in Educational Science, Vol. 22, No. 19, pp. 61-78, 2008

[20] Azimi, Examining ways to improve the quality of schools based on Total Quality Management at schools in Miandoab, MSc Thesis, Tabriz branch, Islamic Azad University, 2007 